\title{
ФОРМУВАННЯ УКРАЇНСЬКО-РОСІЙСЬКОГО БІЛІНГВІЗМУ ВПРОДОВЖ ТРЬОХ ПОКОЛІНЬ (НА ПРИКЛАДІ МІСТА ВІННИЦІ)
}

Ткачук Т. П. Формування українсько-російського білінгвізму впродовж трьох поколінь (на прикладі міста Вінниці).

У дослідженні з'ясовано чинники, які впливають на вибір мови в українськоросійському мовному середовищі в місті Вінниці. Для дослідження обрано соціолінгвістичний метод, за допомогою якого проаналізовано відповіді про використання мови трьома поколіннями респондентів, останнє з яких проживає в місті Вінниці. Загальна кількість опитаних - 400 осіб (старшокласники віком 15 - 17 років).

Ключові слова: українсько-російський білінгвізм, функціонування мови, двомовне середовище.

Ткачук Т. П. Формирование украинско-русского билингвизма на протяжении трех поколений (на примере города Винницы).

В исследовании определены факторы, влияющие на выбор языка в украинскороссийской языковой среде в городе Виннице. Для исследования избран социолингвистический метод, с помощью которого проанализированы ответы об использовании языка тремя поколениями респондентов, последнее из которых проживает в городе Виннице. Общее количество опрошенных - 400 человек (старшеклассники в возрасте $15-17$ лет).

Ключевые слова: украинско-русский билингвизм, функционирования языка, двуязычная среда.

Tkachuk T. P. Formation of Ukrainian-Russian bilingual practices of three generations in the city of Vinnytsia.

In this research, we analyze the language situation in Vinnytsia. Our main research question concerns current Ukrainian-Russian bilingual practices of three generations, the last of whom lives in the city. We examined this question with the method of socio-linguistic survey. The total number of 400 participants represents school students (from 15 to 17 year-old).

Key words: Ukrainian-Russian bilingualism, language use, bilingual environment. 
Виразне двомовне середовище, у якому перебувають громадяни України, суттєво впливає на формування української мови і $є$ предметом дослідження багатьох лінгвістів. Попри те що в Україні державною мовою проголошено українську, чимало українців продовжують переходити на російську мову. Такий інерційний процес особливо помітний у містах і менш виразний у селах та містечках [1, с. 11]. Наше дослідження $\epsilon$ продовженням попереднього [5, с. 97], у якому ми з'ясовуємо чинники, які впливають на вибір мови в українсько-російському мовному середовищі, сформованому історично впродовж останніх кількох століть у місті Вінниці та Вінницькій області.

Для дослідження ми обрали три покоління респондентів, останнє 3 яких проживає в місті Вінниці (Центральна Україна, 370 тисяч жителів). В експертному (усному) опитуванні взяли участь більше 400 осіб - учнів 10-11 класів віком 15-17 років. Для аналізу результатів відібрано 301 анкету. Основну групу опитаних (276 осіб) склали підлітки, що проживають у місті. Контрольну (25 осіб) - діти з містечка Козятин (28 000 жителів за переписом 2001 р.). Усі опитані відповіли на питання, які стосувалися використання української або російської мови ними особисто, їхніми батьками та дідусямибабусями. Після обробки результатів ми позначили першим поколінням дідусів (бабусь), другим - татів (мамів) та третім - опитаних респондентів.

Учням поставили питання про використання мови у спілкування 3 однокласниками, друзями, формальним або ж неформальним лідером поза школою (у дворі, секціях, гуртках тощо). За усіма респондентами проведено спостереження стосовно використання мови в неформальному спілкуванні (на перерві у школі), що дало змогу порівняти отримані результати опитування з реальним використанням мови в комунікативній ситуації. Для обробки результатів ми застосували програму SPSS. Зведена таблиця отриманих даних у місті Вінниці є такою:

\begin{tabular}{|c|c|c|c|}
\hline Питання анкети & Мова & Дівчата & Хлопці \\
\hline \multirow{2}{*}{ Якою мовою спілкується мама? } & Українська & $71,8 \%$ & $68,6 \%$ \\
\hline & Російська & $28,2 \%$ & $31,4 \%$ \\
\hline \multirow{2}{*}{ Якою мовою спілкується тато? } & Українська & $57,6 \%$ & $67,4 \%$ \\
\hline & Російська & $42,4 \%$ & $32,6 \%$ \\
\hline \multirow{2}{*}{ Якою мовою ти спілкуєшся з мамою? } & Українська & $73,0 \%$ & $72,5 \%$ \\
\hline & Російська & $27,0 \%$ & $27,5 \%$ \\
\hline \multirow{2}{*}{ Якою мовою ти спілкуєшся з татом? } & Українська & $64,4 \%$ & $71,4 \%$ \\
\hline & Російська & $35,6 \%$ & $28,6 \%$ \\
\hline \multirow{2}{*}{ Якою мовою говорить (говорив) дідусь (мамин тато)? } & Українська & $76,7 \%$ & $76,1 \%$ \\
\hline & Російська & $23,3 \%$ & $23,9 \%$ \\
\hline \multirow{2}{*}{$\begin{array}{l}\text { Якою мовою говорить (говорила) бабуся (мамина } \\
\text { мама)? }\end{array}$} & Українська & $79,3 \%$ & $81,3 \%$ \\
\hline & Російська & $20,7 \%$ & $18,7 \%$ \\
\hline \multirow{2}{*}{ Якою мовою говорить (говорив) дідусь (татів тато)? } & Українська & $72,4 \%$ & $68,6 \%$ \\
\hline & Російська & $27,6 \%$ & $31,4 \%$ \\
\hline \multirow{2}{*}{$\begin{array}{l}\text { Якою мовою говорить (говорила) бабуся (татова } \\
\text { мама)? }\end{array}$} & Українська & $73,9 \%$ & $67,9 \%$ \\
\hline & Російська & $26,1 \%$ & $32,1 \%$ \\
\hline
\end{tabular}


СТРУКТУРА I СЕМАНТИКА МОВНИХ ОДИНИЦЬ

\begin{tabular}{|l|l|l|l|}
\hline \hline \multirow{2}{*}{$\begin{array}{l}\text { Якою мовою ти спілкуєшся поза школою зі своїми } \\
\text { друзями (у секції, компанії)? }\end{array}$} & Українська & $72,3 \%$ & $68,3 \%$ \\
\cline { 2 - 4 } $\begin{array}{l}\text { Якою мовою переважно спілку-ються твої друзі поза } \\
\text { школою? }\end{array}$ & Уосійська & $27,7 \%$ & $31,7 \%$ \\
\cline { 2 - 4 } $\begin{array}{l}\text { Якою мовою спілкується формаль-ний } \\
\text { (неформальний) лідер у твоїй компанії? }\end{array}$ & Російська & $42,0 \%$ & $63,3 \%$ \\
\hline \multirow{2}{*}{ Якою мовою переважно користується респондент? } & Українська & $67,6 \%$ & $62,4 \%$ \\
\cline { 2 - 4 } & Російська & $32,4 \%$ & $37,6 \%$ \\
\hline Українська & $73,4 \%$ & $80,0 \%$ \\
\hline \multirow{2}{*}{$\begin{array}{l}\text { Чи переходить на іншу мову, коли до нього } \\
\text { звертаються іншою мовою? }\end{array}$} & Так & $26,6 \%$ & $20,0 \%$ \\
\cline { 2 - 4 } & Hі & $42,1 \%$ & $52,8 \%$ \\
\hline
\end{tabular}

У контрольній групі (містечко Козятин) усі 3 покоління (за винятком одного тата, двох дідусів і трьох бабусь) спілкуються українською, однак $66,7 \%$ респондентів переходять на російську, коли до них звертаються російською, що $\epsilon$ свідченням високої конформності користувачів української мови. Спілкування дідусів і бабусь російською мовою ніяк не вплинули на вибір онуками мови, оскільки практично все їхнє оточення виключно україномовне. Тому можна 3 певністю стверджувати, що на периферії домінує українська мова, незалежно від того, що в засобах масової інформації (один із впливових зовнішніх факторів) виразно переважає російська (72\% - Інтернет-сайти, 77\% - газет, 96\% - журналів, що засвідчено нами в попередньому дослідженні [4, с. 240].

В основній групі помітно, що мова, якою говорять батьки респондентів, та мова, якою говорять (говорили) дідусі та бабусі, суттєво впливає на вибір мови респондентом. Зв'язок між мовами батьків і мовою респондентів сильніший, ніж між мовою дідусів і бабусь та мовою респондентів. Зв'язок між мовою, якою спілкується мама, і мовою, якою спілкується респондент, сильніший, ніж між мовою, якою спілкується тато та респондент, проте є діти, які зі своїми батьками спілкуються іншою мовою, тобто існують й інші фактори, що визначають вибір мовцем нерідної мови: наприклад, мовне середовище, у якому діти перебувають поза сім'єю та школою: 14,4\% україномовних респондентів поза школою спілкуються зі своїми друзями російською мовою. Так само впадає у вічі різке зростання користувачів російської мови серед підлітків: $47 \%$ друзів опитаних респондентів спілкуються російською, це за умови, що середній показник респондентів віком 15-75 років, які визнають українську рідною, у Вінниці - 83\% [4, с. 242]. Такий різкий перепад на користь російської важко пояснити, особливо якщо врахувати домінування української мови в офіційній та навчально-діловій сферах (нею користуються в офіційних установах, школах, університетах $80 \%$ респондентів [4, с. 243].

Ще один фактор, який впливає на вибір мовцем мови спілкування у двомовному середовищі, - це мова, передана по материнській та по батьківській лініях. Можемо 3 певністю стверджувати, що термін «материнська мова» виник не безпідставно. Результат нашого опитування 
засвідчив, що у тих сім'ях, де батьки спілкуються різними мовами, діти переважно обирають мову матері: у контрольній групі була лише одна двомовна сім’я, і дитина обрала мову матері - українську. Однак цей випадок не може бути показовим, оскільки діти м. Козятина перебувають в україномовному середовищі (маємо на увазі мову, яка побутує в сім’і та серед друзів). У міському середовищі такі показники є об'єктивнішими. Серед опитаних 276 сімей тридцять є двомовними, зокрема: 9 сімей, де мама російськомовна, а тато - україномовний (українською спілкується 3 дитини, тобто 66,7\% дітей обрали материнську мову - російську); 21 сім'я, де мама україномовна, а тато - російськомовний (українською спілкується 15 дітей, тобто 71,4\% дітей обрали материнську мову - українську).

Незначні зміни у використанні певної мови і в одномовних сім'ях. Наприклад, у разі, якщо обоє батьків україномовні, то їхні діти також користуються вдома українською: у 94 сім'ях 92 дітей розмовляють українською, однак 2 дітей $(2,1 \%)$ обрали для спілкування з батьками російську мову. Інша ситуація в російськомовних сім'ях: у 34 родинах 27 дітей користуються російською $(79,4 \%)$, однак 7 дітей перейшли на українську $(20,6 \%)$. Такий високий показник зміни однієї мови на іншу можна пояснити тим, що дідусі та бабусі цих дітей переважно україномовні, тобто внуки повернулися до рідної мови, яка побутує в найближчому оточенні.

Загалом помітною є тенденція до українізації третього покоління, однак такий прогрес $\epsilon$ дуже невиразним на тлі результатів співвідношення української та російської мов між дідусями (бабусями) та татами (мамами), тобто між першим і другим поколіннями. Наприклад, по материнській лінії впадає у вічі різкий перепад на користь російської мови: 80,1\% бабусь спілкувалися виключно українською, натомість лише 69,8\% їхніх доньок (мамів респондентів) зберегли українську мову як мову міжособистісного спілкування. Різниця - 10\%, натомість лише 7\% внуків знову повернулися до української мови. Позитивнішою $є$ тенденція, яку відстежуємо по батьківській лінії: 70\% бабусь розмовляли українською, 62,6\% татів зберегли українську як рідну, натомість 76,9\% внуків визнали українську як рідну мову. Тому можемо однозначно стверджувати, що у період з 1970 по 1990 роки (друге покоління) відбувався інтенсивний процес русифікації україномовного населення, коли молодь, яка приїжджала в місто, повністю переходила на російську: нами зафіксовано випадки, коли дідусі і бабусі по обох лініях розмовляли виключно українською мовою, а їхні діти, одружившись, обоє переходили на російську.

Серед російськомовних сімей простежуємо інші процеси: по материнській лінії було 46 сімей, де обоє батьків (дідусь і бабуся) користувалися російською, однак 14,3\% мамів перейшли на українську, натомість 29,6\% онуків стали україномовними. По батьківській лінії виявлено 66 російськомовних сімей, у яких 14,5\% змінили мову на українську, натомість аж 65,1\% онуків 
стали україномовними. Такий високий відсоток важко пояснити, однак можна однозначно стверджувати, що україномовні родини інтенсивніше русифікуються у другому і менше - у третьому поколіннях, натомість російськомовні родини інтенсивніше українізуються (особливо по батьківській лінії, що можна пояснити впливом материнської мови) у третьому поколінні. Цілком імовірно, що такий перехід на українську пов'язаний з процесом українізації в державних закладах, особливо в освіті, який припадає на появу третього покоління.

Аналіз конформності дітей з україномовних та російськомовних сімей засвідчує, що діти російськомовних батьків значно конформніші: 84,4\% 3 них переходить на українську мову, якщо до них звертаються українською, натомість лише 38,3\% україномовних дітей переходить на російську, коли до них звертаються російською, проте навіть такий показник є дуже високим, адже етнічних росіян у місті проживає лише 10,2\% (дані перепису 2001 року). Показник мовної конформності в контрольній групі (66,7\% респондентів переходять на іншу мову) відрізняється від отриманого в місті - 55\% респондентів переходять на іншу мову, якщо до них звертаються іншою мовою. Такий відсоток суттєво перевищує отриманий після опитування студентства віком 17-25 років, який засвідчив, що 38\% студентів переходить на іншу мову в комунікативній ситуації [3, с. 142]. Є й інші фактори, які впливають на вибір респондентом мови у двомовних ситуаціях, наприклад, вік та освіта респондентів. У зв’язку з цим Л. Б. Орбан-Лембрик зауважує: «Конформні особи виявляють слабший інтелект, ніж незалежні, їм більше притаманні догматичність, стереотипність мислення, нечіткість думок та висловлювань. Для сфери мотивації та емоційних функцій конформної особи характерні недостатня сила характеру, невміння володіти собою у стресових ситуаціях. У сфері самосвідомості вони страждають комплексом неповноцінності, а в стосунках з іншими проявляють авторитарність, занепокоєність справами інших людей» [2, с. 346]. Можемо стверджувати, що зв'язок між рівнем освіченості та рівнем мовної конформності є обернено пропорційним: вищий рівень освіченості у студентів спричиняє нижчий рівень мовної конформності, хоч можемо припустити, що $є$ й інші фактори, які впливають на мовну конформність студентів, зокрема те, що більшість із них - вихідці з периферії.

Практично не впливає на вибір мови належність до певної статі, однак помітно, що дівчата більш російськомовні (за нашими спостереженнями у вільному спілкуванні на перерві 73,4\% дівчат і 80\% хлопців користуються українською) і коло спілкування в дівчат теж більше російськомовне (48\% друзів користуються російською, а у хлопців - 36,7\%), дівчата частіше переходять на іншу мову, ніж хлопці: 57,9 / 52,8\%. Однак під час опитування виявлено, що хлопці поза школою (з друзями, у секції, компанії) частіше переходять на російську - 31,7\% (майже на 12\% більше, порівняно зі спілкуванням у школі). Дівчата і в школі $(73,4 \%)$, і поза школою $(72,3 \%)$ у спілкуванні 3 друзями демонструють відносну стабільність у користуванні українською. 
Отже, рівень мовної конформності хлопців вищий, ніж у дівчат.

Натомість у другому та третьому поколінні жінки більш україномовні, ніж чоловіки: 69,8\% мам спілкуються українською і 76,1\% / 80,1\% дідусівбабусь відповідно, натомість 62,6\% татів спілкується українською та 70,1\% / 70,4\% дідусів-бабусь по батьківській лінії спілкуються українською.

Суттєво впливає на вибір мови респондентом мовне середовище друзів: 46,1\% респондентів 3 друзями (поза школою) спілкуються російською, за умови, що 78\% опитаних у вільному спілкуванні на перерві користуються українською. Майже не впливає на вибір респондента мова, якою спілкується формальний (неформальний лідер), оскільки 75\% лідерів компаній (гуртків, секцій) користуються українською.

Отже, функціонування російської мови у сфері міжособистісного спілкування, у неформальних ситуаціях поза родиною та професійною сферою зумовлене не кількісним переважанням росіян, а комунікативною потужністю російської мови, яка стала мовою урбанізованого суспільства. Серед факторів, які спричиняють вибір мови респондентом, ми виокремили такі, як вплив материнської мови, мовна конформність, стать респондента та мова друзів. Наше дослідження потребує уточнення стосовно впливу урбаністичного соціуму на вибір мовцем української або російської мови в різних сферах спілкування, тому наступним кроком буде з'ясування рівня освіти та походження кожного $з$ представників трьох поколінь (з міста чи периферії), що дасть змогу точніше відстежити тенденцію до переходу саме на міську (російську) мову представників третього покоління.

\section{Література}

1. Залізняк Г. Мовна ситуація Києва: день нинішній та прийдешній / Г. Залізняк, Л. Масенко // Українознавчі зошити журналу «Урок української». - К., 2002.

2. Орбан-Лембрик Л. Е. Соціальна психологія. Кн. 1 : Соціальна психологія особистості і спілкування / Л. Е. Орбан-Лембрик. - К. : Либідь, 2004.

3. Пастушина I. I. Вплив соціальних мереж на формування українсько-російської двомовності студентів вінницьких ВИШів / І. І. Пастушин // Філологічні студії : зб. наук. праць студентів. - Вінниця, 2013. - Вип. 11. - С. 140-144.

4. Ткачук Т. П. Зовнішні та внутрішні чинники, які впливають на українськоросійську двомовність в пострадянському місті (на прикладі міста Вінниці) / Т. П. Ткачук // Теоретична і дидактична філологія : зб. наук. праць. - ПереяславХмельницький, 2012. - Вип. 12. - С. 239-243.

5. Tkachuk Taras. Ukrainian-Russian Bilingualism in Urban Settings / Taras Tkachuk // Sociolinguistics Symposium 19. - Berlin, Aug 21-24, 2012. - P. 97. 